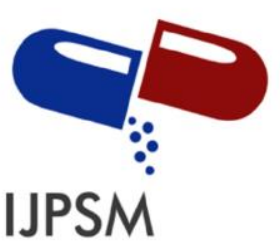

Winda Wulandari et al, Int. Journal of Pharmaceutical Sciences and Medicine (IJPSM), Vol.6 Issue. 1, January- 2021, pg. 83-91

ISSN: 2519-9889

Impact Factor: 3.426

\title{
Review: Black Pepper (Piper Nigrum L.) Botanical Aspects, Chemical Content, Pharmacological Activities
}

\author{
Winda Wulandari $^{1}$; Maria Dona Octavia ${ }^{1}$; Yeni Novita Sari ${ }^{1}$; Harrizul Rivai ${ }^{2}$ \\ ${ }^{1}$ School of Pharmaceutical Science (STIFARM) Padang 25174, Indonesia \\ ${ }^{2}$ Faculty of Pharmacy, Andalas University, Limau Manih Campus, Padang 25163, Indonesia \\ E-mail: wwulandari291@ gmail.com \\ DOI: 10.47760/ijpsm.2021.v06i01.007
}

\begin{abstract}
Black pepper spices have many benefits in life. The most commonly used service is as a spice in the kitchen because it has a distinctive taste. Black pepper is one of the oldest spices and is most widely used for cooking and in the health sector, namely traditional medicine called the "king of spices."The data collection was sourced from the internet, such as Google Scholar, Researchgate, Science direct, books on black pepper, and trusted journal publishers from 2000-2020. Traditional medicine uses plants that exist in nature, such as roots, stems, branches, leaves, flowers, and fruits that are easier to obt ain. Besides not having side effects, they can also be used for a long time. The main content of piperine and essential oil from black pepper has many pharmacological effects, including an antioxidant, antifungal, antimicrobial, antiepileptic, increases libido, anti-diarrhea and others. Based on this, a lot of research has been done on black pepper's chemical content and its pharmacological effects.
\end{abstract}

Keywords: Black pepper (Piper nigrum L.), botanical aspects, chemical content, pharmacological activity.

\section{Introduction}

Spices have a definition of plants used to improve the taste of food, including the skin, flowers, fruit, roots, leaves, rhizomes, seeds, tubers, and other plant parts. Spices are aromatic or intensely flavored parts of plants used in small quantities in foods as preservatives or flavoring in cooking [1].

Indonesia is a country that has abundant spices, one of which is pepper. There are two types of pepper, namely black pepper and white pepper. Black pepper (Piper nigrum L.) is such a useful medicinal plant that black pepper is called the "king of spices" [2].

Black pepper is used throughout the world for various types of dishes. Black pepper is also used in medicine for multiple types of diseases since centuries ago. Black pepper is useful in treatment, preservatives, and flavorings [3], the cosmetic industry, the perfume industry and is widely used as a medicinal ingredient, both in a single form and in mixed conditions with other components [4]. In Indonesia, pepper (Piper nigrum L.) is used as an antimicrobial, antihypertensive, anti-plasma, anti-inflammatory, hepatoprotective and antioxidant [2].

Black pepper used for generations (empirically) has long been known in Indonesian [5]. Therefore the authors are interested in reviewing black pepper, both from its botanical aspects, chemical content, and the pharmacological activity of black pepper (Piper nigrum L.). 


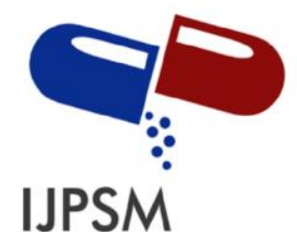

\section{Winda Wulandari et al, Int. Journal of Pharmaceutical Sciences and Medicine (IJPSM), Vol.6 Issue. 1, January- 2021, pg. 83-91}

ISSN: 2519-9889

Impact Factor: 3.426

\section{Data Collection}

In compiling this review article, the technique used is to use literature review by looking for sources or literature in the form of primary data or official book forms and national and international journals in the last 20 years (2000-2020) then making this review article and searching for data using online media with the keywords Piper nigrum L., the chemical content of Piper nigrum L. and the pharmacological activity of Piper nigrum $\mathrm{L}$. The primary references used in this review article look for them through trusted websites such as ScienceDirect, ResearchGate, Google Scholar, and other published and relied on journals.
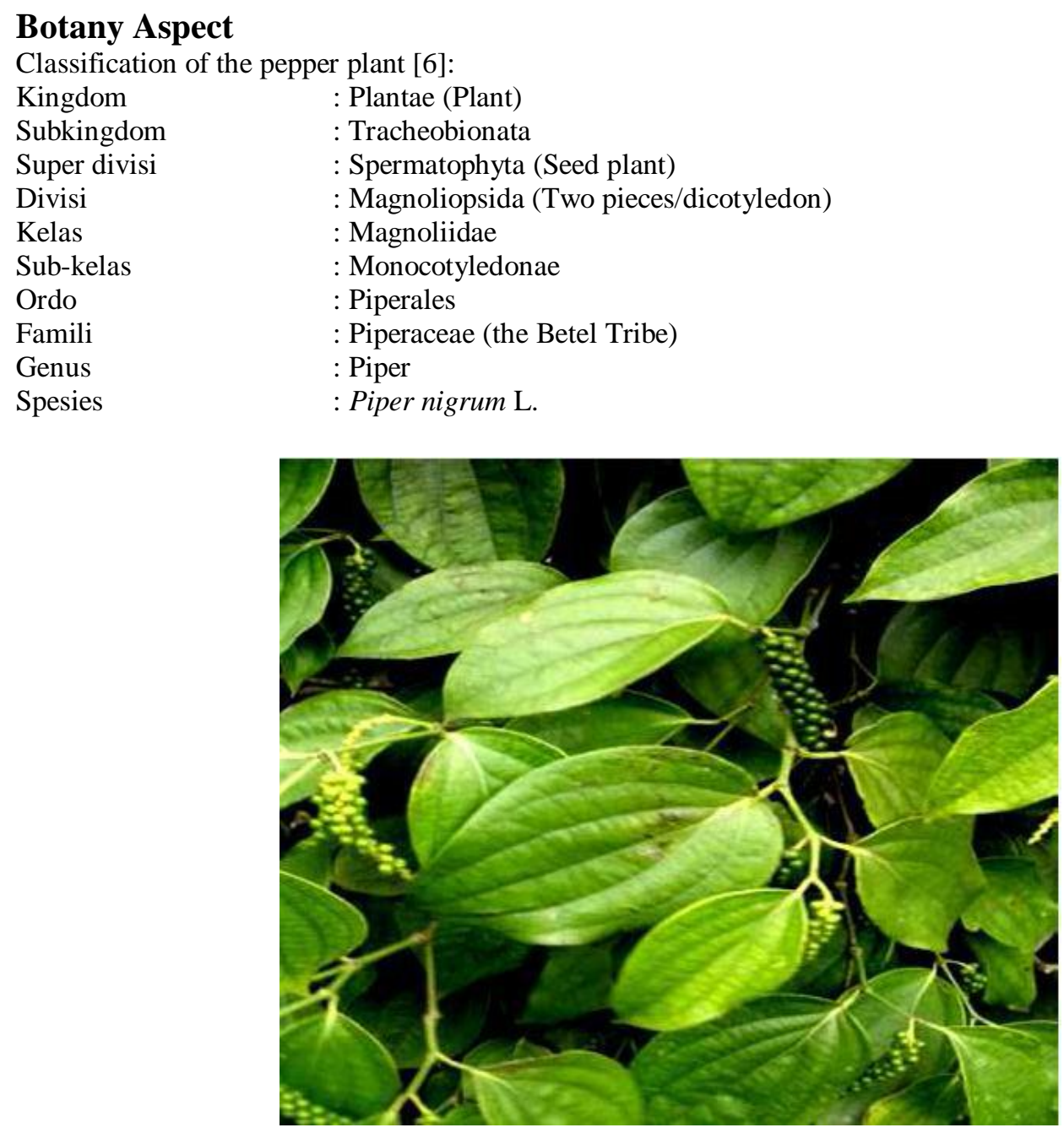

Figure 1: Black pepper plant (Piper nigrum L.) [7]

Morphologically, the pepper plant is a perennial that climbs and spreads (Figure 1). The stem is broad, and it has knuckles - a plant height of up to 10 meters and a crown diameter of up to 1.5 meters. Pepper plant parts include roots, stems and branches, leaves, flowers, fruit, and seeds [8].

There are two types of pepper plant roots: roots that grow from hoops in the soil-forming lateral knuckles, which function as an absorbent of nutrients, and roots that grow above the ground, which act as adhesive roots. 


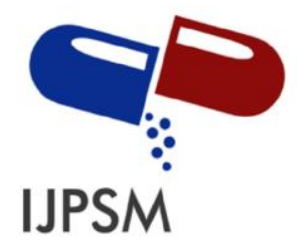

\section{Winda Wulandari et al, Int. Journal of Pharmaceutical Sciences and Medicine (IJPSM), Vol.6 Issue. 1, January- 2021, pg. 83-91}

ISSN: 2519-9889

Impact Factor: 3.426

The pepper plant's lateral roots are filamentous at the bottom of the stem and are the taproot. The number of pepper roots is 10-20, with a length of 3-4 meters. Pepper roots can penetrate the soil to a depth of 1-2 meters. The adhesive roots that grow from the stem's knuckles on the ground are not elongated. Their length is quite limited, ranging from $3-5 \mathrm{~cm}[8]$.

The stem of the pepper plant is like a long, cylindrical vine and knuckles. Young stems are green, while old stems are woody with a diameter of $4-6 \mathrm{~cm}$. The knuckle can reach $5-12 \mathrm{~cm}$ in length. The pepper plant is a dimorphic plant with two main types of vines, namely climbing tendrils and fruit tendrils. The climbing tendrils have nodes with knuckles that form long, sticky roots that do not have the potential to bear fruit. The fruit tendrils (branches) have a sympodial branching system and grow horizontally (plagiotrope). The tendrils of the fruit do not have a root attached to the knuckles. Fruit tendrils are phototropic positive, while climbing tendrils are phototropic negative. In addition to these two types of tendrils, pepper plants are also known as hanging tendrils and soil tendrils. Hanging tendrils are tendrils that grow depending on the canopy surface, while soil tendrils grow along the surface of the soil. Both of them have relatively long knuckles. The stems have more diameter, the leaves are narrower, and do not have attached roots. Anatomically hanging tendrils and soil tendrils come from climbing tendrils. Both are inferior tendrils and so are usually removed by trimming [8].

Pepper leaves are round like eggs, asymmetrical in shape with a tapered tip, sitting single leaves, growing alternately on each stem knuckle. The length of the petiole ranges from $1.8-2.6 \mathrm{~cm}$, the base of the leaves is blunt and notched, the tips of the leaves are tapered, the shape of the leaves varies from oval to heart-shaped (cordatus). The width ranges from $5-10 \mathrm{~cm}$ and $10-19 \mathrm{~cm}$ long. The leaf bones consist of the mother bone (rib) and the branch bones (lateral nerves) curved in 3-4 pairs [8].

The pepper plant has panicle-shaped flowers, about 3-25 cm long, unbranched, single-axis where more than 150 small flowers grow per bunch and grow opposite the branches' leaves. The pepper flower is a compound flower. The color is light greenish-yellow. The panicles hang down in varying lengths. There are pepper flowers that flower only females, only male flowers, or hermaphrodite (bisexual). Single-celled female genitals consist of 1 ovule. Three hundred five stigmas surround the ovary. On the left/right of the female genitals, there are 2-4 short stamens, each containing two pockets of essence (theca). Pepper flowers are protogenic. The flower candidates were initially eyes. Towards the flowering period, the sprout grows into a bud covered with a leaf sheath [8].

Pepper fruit is generally round or slightly oval. There are three types of fruit, like ordinary fruit, which is green when ripe and red-orange. Fruits that are not normal are small and dark green and will turn black. Pepper's skin is 1-2 mm thick. The skin is hard on young fruit, on ripe fruit, the soft, juicy skin is red-orange and peels easily. The fruit contains essential oils, oleoresin, and piperine, which have different contents in several varieties [8].

Pepper seeds have a white, brown seed coat and smooth surface with a 3-4 mm diameter. The embryo is located near the seed hole (microfilm). The oil content is found in the seed coat [8]. In some areas, the pepper fruit is known as pedes, saang, sakang, or merica [9].

Pepper grows well in areas with an altitude of $0-500 \mathrm{~m}$ above sea level, but it is best at the height of $100 \mathrm{~m}$ above sea level. The desired rainfall ranges from $20003000 \mathrm{~mm}$ per year with two dry months to encourage flowering. Rain and wind that are too heavy will shed a lot of flower stalks and fruit bunches rarely. The best air temperature range is $23-32^{\circ} \mathrm{C}$ with daytime temperatures of $29^{\circ} \mathrm{C}$. The soil of interest is light, loose, welldrained, and fertile. Pepper plants are not commonly grown from seed. The seeds are obtained from ripe fruit, massaged to remove the seeds, washed, and wind-dried. Immediately sow the seeds in sand beds, 3-4 weeks after the seedlings will grow. Seedlings at the age of 2 months can be transferred to the main nursery. One meter-long 7-segment cuttings can be planted directly in the garden, while short cuttings, 1-3 segments need to 


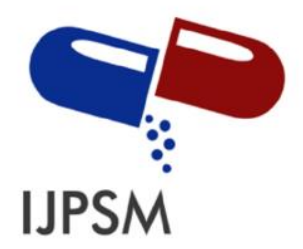

\section{Winda Wulandari et al, Int. Journal of Pharmaceutical Sciences and Medicine (IJPSM), Vol.6 Issue. 1, January- 2021, pg. 83-91}

be seeded first. One book cuttings (one leaf) sown on a sand bed, after sprouting within 1-2 months it can be transferred to a plastic bag. Seedlings are kept under the roof for about 3-4 months, reaching a length of 7 sections, ready for planting into the garden [10].

\section{Chemical Content}

The chemical content in black pepper is saponins, flavonoids, essential oils, chavisin, resins, egg white, starch, piperine, piperylline, piperoleine, piperanine, dihydrocarveol, karyo fillene oxide, cariptone, tran piocarrol, and pepper oil [11].

\section{Saponin}

Based on the research carried out regarding the phytochemical analysis of the Piper nigrum L. quantitatively using the Folin-Ciocalteu method, the results showed that saponins' presence was $0.06 \%$ in the Piper nigrum L. extract [12]. Tannins and saponins in Piper nigrum L. extract function to protect against hypercholesterolemia and are antibiotic [13].

\section{Flavonoids}

The study obtained phytochemical screening results, which showed that the simplicia Piper nigrum L. was positive (+) containing flavonoids [14]. Another study explained that Piper nigrum L. fruit extract contains flavonoid compounds by testing the methanol extract of Piper nigrum L. using the UV spectrophotometric method. And the total flavonoid content in methanol extract of Piper nigrum L. fruit was $(1.7281 \pm 0.0490)$ $\mathrm{mg} / \mathrm{g}$ and $(1.087 \pm 0.002) \mu \mathrm{g} / \mathrm{g}[15]$.

\section{Essential Oils}

The study explained that by isolating essential oil from black pepper (Piper nigrum L.) using $2.2 \mathrm{~kg}$ of ground black pepper, separated by steam distillation for \pm 6 hours adjusted based on the optimum time of essential oil distillation with SNI 0005: 2013 concerning black pepper. The essential oil from black pepper obtained is added with anhydrous $\mathrm{Na}_{2} \mathrm{SO}_{4}$, which functions to remove the watercress. The resulting essential oil was 28 $\mathrm{mL}$ with a yield of $1.27 \%$ [16].

Another study isolated essential oils using 200 grams of fresh peppercorn, dried pepper fruit, and pepper leaves distilled with water for 5 hours in a Clevenger device. The yield of essential oils obtained was $2.2 \%$ from fresh pepper fruit, $2 \%$ from dried pepper fruit, and 1.2\% from pepper leaves. This experiment was carried out three times, and the average value was taken [17].

\section{Chavicine}

Piperine has four isomeric structures, namely piperine (trans-trans isomer), isopiperine (cis-trans isomer), chavicine (cis-cis isomer), and isochavicine (trans-cis isomer) (Figure 2). 


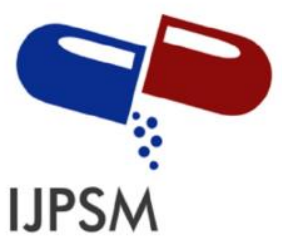

\section{Winda Wulandari et al, Int. Journal of Pharmaceutical Sciences and Medicine (IJPSM), Vol.6 Issue. 1, January- 2021, pg. 83-91}

ISSN: 2519-9889<smiles>CC1Oc2ccc(/C=C/C=C/C(=O)N3CCCCC3)cc2O1</smiles><smiles>CC1Oc2ccc(/C=C/C(=O)N3CCCCC3)cc2O1</smiles><smiles>O=C(/C=C/c1ccc2c(c1)OCO2)N1CCCCC1</smiles>

Chavicine<smiles>CC1Oc2ccc(/C=C/C=C/C(=O)N3CCCCC3)cc2O1</smiles>

Figure 2: Chemical Structure of Piperine, Isopiperine, Chavicine, Isochavisin [18].

\section{Piperine}

Piperine (piperinoyl-piperidine) is a hot, nitrogenous substance found in black pepper. Pepper contains the main active ingredient, namely piperine, which belongs to the pyridine group and is used as an ingredient in cough medicine, anti-malaria, and anti-inflammatory. Piperine content of pepper is average $6 \%$, but if in the form of oleoresin, it contains piperine as much as $25.74 \%$ to $48.32 \%$ [19]. The piperine alkaloid isolated from pepper functions as an antimicrobial, antioxidant, anti-inflammatory, anti-cancer, anti-depressant (relaxant), and an analgesic [7].

The tests that have been carried out show that in the black pepper fruit and white pepper fruit (Piper nigrum L.) extracted with various ethanol concentrations using the TLC-Densitometry method, there is a piperine content. Determination of piperine levels in the alkaloid fraction of black pepper fruit using the TLC-densitometry method shows that the highest piperine content is in the alkaloid fraction of the black pepper fruit ethanol extract extracted using $60 \%$ ethanol as much as $52.81 \%$. According to the researcher, the greater the ethanol concentration, the smaller the piperine content in the black pepper fruit extract [20].

Another study showed the determination of piperine levels in black pepper (Piper nigrum L.) fruit extract use the Liquid Chromatography-Tandem Mass Spectrometry (LC-MS / MS) method. The piperine content of 96\% ethanol extract from black pepper in this study was obtained using the LC-MS method is $26 \%$ [21].

\section{Piperylline, Piperoleine, Piperanine}

Singh et al. (2004) described black pepper extract containing piperine (33.53\%) and followed by piperoleine B (13.73\%) [22]. Apart from piperine, none of the isomers have a spicy taste. However, piperanine, piperettine, piperyllin A, piperoleine B, and piperine in black pepper extract give a slightly tangy taste [23].

\section{Pharmacological Activities}

Some literature reports that black pepper has various pharmacological activities, among others:

\section{Antioxidants}

Antioxidant activity of leaf extracts on four plants of the piper family, namely Piper nigrumL., Piper aduncum, Piper retrofractum, and Piper crocatum, make a mother liquor with a concentration of $100 \mu \mathrm{g} / \mathrm{mL}$ and made with five series of dilutions each and vitamin $\mathrm{C}$ as a standard. Samples and standards dissolved in methanol 


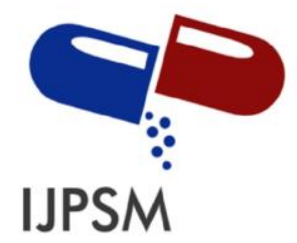

\section{Winda Wulandari et al, Int. Journal of Pharmaceutical Sciences and Medicine (IJPSM), Vol.6 Issue. 1, January- 2021, pg. 83-91}

ISSN: 2519-9889

Impact Factor: 3.426

were added with DPPH stock solution with a volume ratio of 1: 1. Absorption was measured using UV-Vis Spectrophotometry at a wavelength of $516 \mathrm{~nm}$ [24]. The results showed that the ethanol extract of Piper nigrum L. leaves had the highest antioxidant activity with an IC50 value of $57.72 \mu \mathrm{g} / \mathrm{mL}$, and according to the antioxidant activity classification, the ethanol extract of Piper nigrum L. leaves had vigorous antioxidant activity [14][24].

Flavonoids with a flavone and flavanone structure framework have potent antioxidant activity due to a hydroxyl group's presence on ring $\mathrm{B}$ and substitution of $\mathrm{C} 3$ carbon in ring $\mathrm{C}$ [25].

Other studies have also proven that Piper nigrum L. provides antioxidant effects using the cold extract of Piper nigrumL.and even methanol DPPH. And the results were obtained on the antioxidant activity of $78.81 \%$ with $200 \mu \mathrm{g} / \mathrm{mL}$ [26]. Piper nigrum L. has antioxidant potential due to flavonoids and phenolic content [2][26].

\section{Antimicrobials}

The disc diffusion method's antimicrobial effect of Piper nigrum L. extract was carried out using different extracts. Antibacterial tests were carried out using the Muller-Hilton agar disc diffusion method, followed by the CLSI procedure. And the results obtained were the hot and cold extraction methods of black pepper leaves methanol extract showed an effect on E. Coli through the disc diffusion method [26]. Phenolic phytochemical compounds are the most widely distributed of the pentose phosphate derivatives, shikimate, and phenylpropanoid pathways in plants. These secondary metabolites play an important role in reproduction and growth. These compounds also protect harmful pathogenic microbes and predators [27].

\section{Increase Libido}

Research has proven the effect of black pepper (Piper nigrum L.) extract on male mice (Mus musculus L.) libido of different ages. The method of testing libido is done by testing the marriage at the end of the treatment time. And the results showed that black pepper extract was able to increase libido in mice by shortening the riding latency in old male mice, shortening the latency of riding, and increasing the frequency of riding in young male mice [28].

The active substance of black pepper is functions as an antioxidant that can improve fitness. The vomeronasal organ can adequately detect male mice's olfactory power against the pheromones released by female mice. This pheromone signal is then transmitted to the amygdala as well as MPOA (Medial Preoptic Area). The active substance piperine from black pepper can increase the gonadotropin hormone in serum by inhibiting negative feedback to the pituitary in male mice (29). Testosterone itself is an important hormone that acts on the amygdala and MPOA. Testosterone plays a role in regulating sexual behavior, significantly increasing sensory input processing to pheromone stimuli, thus playing a role in the activity of forging [30].

Another study also explained that black pepper fruit extract influences sexual arousal in male mice by examining mating behavior in experimental animals [31].

\section{Antibacterial}

Testing for the antibacterial effect uses Staphylococcus aureus and Escherichia coli bacteria. Based on the results of the research that has been done, it shows that the ethanol extract of pepper leaves has high activity. Namely as much as $8.3 \%$ against Staphylococcus aureus and Escherichia Coli bacteria, namely $7.73 \%$ compared to the ethyl acetate extract of pepper leaves, but it does not inhibit fungi. C. Albicans. Both extracts of pepper leaves have activity in inhibiting the growth of all three types of microbes [32]. The antimicrobial activity of pepper leaves is because pepper leaves have active compounds, namely tannins, phenols, coumarin, alkaloids, and anthraquinones. The alkaloid content of 5-9\% contains the main compounds piperine, piperidine, piperetin, and piperazine [33].

Research also explains that black pepper chloroform extract can inhibit food spoilage and pathogenic food bacteria. Black pepper chloroform extract can provide an antimicrobial effect against Escherichia coli and Staphylococcus aureus by looking at the antibacterial mechanism of black pepper chloroform extract by analyzing cell morphology, respiratory metabolism, pyruvic acid content, and ATP levels of target bacteria [34].

\section{Anti-Seizure}

A study for its anti-seizure pharmacological effect using one intraperitoneal injection of pentylenetetrazole (PTZ at a $75 \mathrm{mg} / \mathrm{kg}$ ) dose in animals was found to induce tonic-clonic seizures (1.79-0.32 minutes long), which 


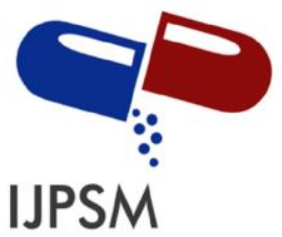

\section{Winda Wulandari et al, Int. Journal of Pharmaceutical Sciences and Medicine (IJPSM), Vol.6 Issue. 1, January- 2021, pg. 83-91}

ISSN: 2519-9889

Impact Factor: 3.426

reached a peak of $100 \%$ mortality. Animals treated with Diazepam (5mg/kg administered IP) failed to show signs of seizures and avoided death. The dose of piperine given was $5 \mathrm{mg}, 10 \mathrm{mg}$, and $20 \mathrm{mg}$. Treatment with piperine at doses of 5 and $20 \mathrm{mg} / \mathrm{kg}$ failed to show protection against death, but piperine at a dose of $10 \mathrm{mg} / \mathrm{kg}$ provided $60 \%$ protection against death in PTZ-induced seizures [35].

In-vivo studies showed that piperine delayed significantly with seizure onset in the PTZ-induced seizure test, suggesting the possible involvement of the GABA A receptor and glycinergic signaling pathways. The acute effect of piperine on cortical and hippocampal GABA levels suggests that piperine treatment increases GABA levels in this area and is suitable as an anticonvulsant effect in PTZ testing [35].

\section{Antidiarrheal}

Research shows that black pepper extract exerts antidiarrheal activity. It uses experimental animals with its inducers of castor oil, magnesium sulfate, small intestinal transit, and small intestinal secretions leading to inhibition of diarrhea at a dose of $300 \mathrm{mg} / \mathrm{kg}$ compared to the control group. Black pepper extract provides antidiarrheal effects through its anti-secretion (gastric acid) and antimotility due to the delay in gastrointestinal transit induced by black pepper extract, contributing to the antidiarrheal activity and allows more time for absorption. The researcher explained that the phytochemical analysis showed that carbohydrates and alkaloids were the constituents or the central part responsible for the anti-secretory and antimotility activities, thus providing a scientific basis that black pepper extract could provide antidiarrheal effects [36].

Other studies have also shown that the piperine in black pepper extract can reduce the secretion of liquid induced from castor oil. Piperine from black pepper at a dose of $20 \mathrm{mg} / \mathrm{kg}$ given orally can significantly reduce fluid accumulation in mice's small intestine [37].

\section{Conclusion}

Black pepper (Piper nigrum L.) is a type of spice used in cooking spices. With a distinctive and spicy taste, many people use it as a kitchen ingredient. Black pepper grows by climbing and creeping above the ground. Black pepper has chemical properties such as piperine and essential oils widely used in traditional medicine. The pharmacological effects given from this black pepper include antioxidant, antimicrobial, increasing libido in experimental animals, antibacterial, anti-seizure, and anti-diarre.

\section{References}

[1] No Title [Internet]. Available from: https://id.wikipedia.org/wiki/Rempah-rempah

[2] Damanhouri ZA, Ahmad A. A Review on Therapeutic Potential of Piper nigrum L. (Black pepper): The King of Spices. Medicinal and Aromatic Plants. 2014;3(3). 3-6. Available from: http://dx.doi.org/10.4172/21670412.1000161

[3] Ahmad N, Fazal H, Abbasi BH, Farooq S, Ali M, Khan MA. Biological role of Piper nigrum L. (Black pepper): A Review. Asian Pac J Trop Biomed. 2012;1691

[4] Ali AA, Ahmad J, Kapoor P, Jahangir U, Parveen S, Khan QA. Efficacy of Piper nigrum(Black pepper): A Review. 2016;4(4):5-7.

[5] Boangmanalu RK, Zuhrotun A. Review Artikel : Potensi Khasiat Obat Tanaman Marga Piper : Piper nigrum L., Piper retrofractum Vahl., Piper betle Linn., Piper cubeba L. dan Piper crocatum Ruiz \& Pav. Farmaka. 2018;16(3):204-12.

[6] No Title [Internet]. Available from: http://plantamor.com/species/info/piper/nigrum

[7] Vasavirama K, Upender M. Piperine : A Valuable Alkaloid From Piper Species. Int J Pharm and Pharm Sci. 2014;4(4).34-38.

[8] Yudiyanto. Tanaman Lada dalam Perspektif Autekologi. Bandar Lampung: Anugrah Utama Raharja; Bandar Lampung. 2016.1-128 hal.

[9] Utami P, Lentera T. Tanaman Obat Untuk Mengatasi Rematik \& Asam Urat. Depok : Pt.Agromedia Pustaka.2006.1-124 hal. 


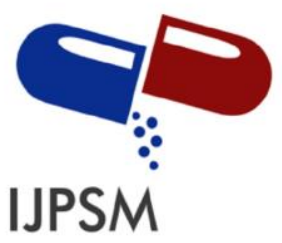

\section{Winda Wulandari et al, Int. Journal of Pharmaceutical Sciences and Medicine (IJPSM), Vol.6 Issue. 1, January- 2021, pg. 83-91}

ISSN: 2519-9889

Impact Factor: 3.426

[10] Evizal R. Tanaman Rempah dan Fitofarmaka. Badar Lampung : Lembaga Penelitian Bandar Lampung : 2013. 1196 hal.

[11] Cholis N. Ensiklopedia Obat-Obatan Alami. Jawa Tengah : Alprin Semarang Selatan. 2010. 1-130 p.

[12] Ali M, Shinkafi S., Farouk SNF. Phytochemistry and Antibacterial Activity of Black Pepper (Piper nigrum) Seeds Extracts on Some Food-Borne Pathogens. Int J Pharm Sci Kosm Publ. 2018;1(1):1-8.

[13] Okwu D. Evaluation Of The Chemical Composition Of Indigenous Spices and Flavouring Agents. Glob J Pure Appl Sci. 2001;7(3):455-459.

[14] Insane M, Marliani L, Dinilah NP. Comparison of Antioxidant Activities from Four Species of Piper. Pharmacia. 2017;7(2):305-312.

[15] Ahmad A, Husain A, Mujeeb M, Khan SA, Alhadrami HAA, Bhandari A. Quantification of Total Phenol, Flavonoid Content and Pharmacognostical Evaluation Including HPTLC Fingerprinting for the Standardization of Piper nigrum Linn fruits. Asian Pac J Trop Biomed. 2015;5(2):101-107. Available from: http://dx.doi.org/10.1016/S2221-1691(15)30152-0

[16] Anggraini R, Jayuska A, Alimuddin AH. Isolasi dan Karakterisasi Minyak Atsiri Lada Hitam (Piper nigrum L.) Asal Sajingan Kalimantan Barat. J Kim Khatulistiwa. 2018;7(4):124-133.

[17] Sasidharan I, Menon AN. Comparative Chemical Composition and Antimicrobial Activity of Berry and Leaf Essential Oils of Piper nigrum L .Intel J Bio Med Res. 2010;1(4):215-218.

[18] Ternes, W.; Krause, E. L. Characterization and Determination of Piperine and PiperineIsomers in Eggs. Anal. Bioanal. Chem.2002;374(1);155-160.

[19] Dang QT, Phan N. Optimization of Supercritical CO 2 Extraction of Oleoresin From Black Pepper (Piper nigrum L .) and Antioxidant Capacity of the Oleoresin. Int Food Res J. 2014;21(4):1489-1493.

[20] Hikmayanti NPE, Hariyanti, Aulia C, Viransa VP. Kandungan Piperin Dalam Ekstrak Buah Lada Hitam dan BuahLada Putih (Piper nigrum.L) yang Diekstraksi dengan Variasi Konsentrasi Etanol Menggunakan Metode KLT-Densitometri. Media Farm. 2016;13(2):173-185.

[21] Febriyanti AP, Iswarin SJ, Susanti. Penetapan Kadar Piperin dalam Ekstrak Buah Lada Hitam (Piper nigrum Linn.) Menggunakan Liquid Chromatography Tandem Mass Spectrometry (LC-MS/MS). J Ilm Farm Farmasyifa. 2016;1(2):69-79.

[22] Singh G, Marimuthu P, Catalan CA, deLampasona MP. Chemical, Antioxidant and Antifungal Activities of Volatile Oil of Black Pepper and its Acetone Extract. J Sci Food Agriculture. 2004;1878-1884.

[23] Gorgani L, Mohammadi M, Najafpour GD, Nikzad M. Piperine - The Bioactive Compound of Black Pepper : From Isolation to Medicinal Formulations. Compr Rev inFood Sci Food Saf. 2017;16:129-140.

[24] Molyneux P. The Use of the Stable Free Radical Diphenylpicryl- hydrazyl ( DPPH ) for Estimating Antioxidant Activity. Songklanakarin J Sci Technol. 2004;26(2):211-219.

[25] Heim KE, Tagliaferro AR, Bobilya DJ. Flavonoid Antioxidants : Chemistry, Metabolism Flavonoid Antioxidants : Chemistry, Metabolism and Structure-Activity Relationships. The Journal Nutr Biochem. 2002;13:572-584.

[26] Sapam R, Kalita PP, Sarma MP, Talukdar N, Das H. Screening of Phytochemicals and Determination of Total Phenolic Content, Antioxidant and Antimicrobial Activity of Methanolic Extract of Piper Nigrum Leaves. Indo Am J Pharm Res. 2018;8(2).1354-1360. Available from: https://www.researchgate.net/publication/323613522

[27] Eleazu CO, Eleazu KC, Awa E, Chukwuma SC. Comparative Study of the Phytochemical Composition of the Leaves of Five Nigerian Medicinal Plants. J Biotechnol Pharm Res. 2012;3(2):42-46.

[28] Ekaputri TW, Kanedi M, Sutyarso, Busman H. Effect Of Black Pepper (Piper nigrum L.) Extract On Male Mice (Mus musculus L.) Libido Of Different Age. j Biologi Eksperimen dan Keanekaragaman Hayati. 2014;2(1):1-5.

[29] D'Cruz SC, Mathur PP. Effect of Piperine on the Epididymis of Adult Male Rats. Asian J Androl . 2005;7(4):363368. Available from: https://www.researchgate.net/publication/7487318 Effect

[30] Hull EM, Muschamp JW, Sato S. Dopamine and Serotonin : Influences on Male Sexual Behavior. J Physiology \& Behavior. 2004;291-307.

[31] Kanedi M, Rosa E. Effects of Black Pepper ( Piper nigrum Linn .) Extract on Sexual Drive in Male Mice. Res Journal of Medical Plant. 2015;9(1):42-47.

[32] Hartati, Pagarra H. Differences of Ethanol Extract and Ethyl Acetate of Pepper Leaf (Piper Nigrum L ) Against Anti Microbial Activity. Jurnal Sainsmat. 2018; VII(1):1-7.

[33] Kadam P., Yadav KN, Patel FA., Karjikar, Patil MJ. Pharmacognostic, Phytochemical and Physicochemical Studies of Piper nigrum Linn. Fruit (Piperaceae). Int Res J Pharm. 2013;4(5). 189-193.

[34] Zou L, Hu YY, Chen WX. Antibacterial Mechanism and Activities of Black Pepper Chloroform Extract. J Food Csi Technol. 2015:1-8.

[35] Mishra A, Punia JK, Bladen C, Zamponi GW, Mishra A, Punia JK, Zamponi GW, Goel RK. Anticonvulsant Mechanisms of Piperine, a Piperidine Alkaloid. Taylor \& Francis Group. 2015;317-323. 


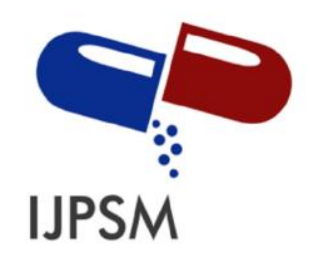

Winda Wulandari et al, Int. Journal of Pharmaceutical Sciences and Medicine (IJPSM), Vol.6 Issue. 1, January- 2021, pg. 83-91

ISSN: 2519-9889

Impact Factor: 3.426

[36] Shamkuwar PB, Shahi SR, Jadhav ST. Evaluation of Antidiarrhoeal Effect of Black Pepper (Piper nigrum L.). Pelagia Research Library. 2012;2(1):48-53.

[37] Capasso R, Izzo AA, Borrelli F, Russo A, Sautebin L, Pinto A, Capasso F, Mascolo N. Effect of Piperine, the Active Ingredient of Black Pepper, on Intestinal Secretion in Mice. Life Sciences. 2002;71:2311-2317. 